\title{
Prevalence and medical management of erectile dysfunction in Asia
}

\begin{abstract}
Kwangsung Park, Eu Chang Hwang and Sun-Ouck Kim
Erectile dysfunction (ED) is an important worldwide health issue that has a significant negative impact on the quality of life and life satisfaction of both the affected individual and his partner. Here we review the prevalence of ED in Asia, associated factors that may influence sexual attitudes and sexual behaviours, and randomized clinical trials (RCTs) of phosphodiesterase-5 (PDE-5) inhibitors to evaluate the clinical efficacy and safety of PDE-5 inhibitors in Asian men. We searched for English-language articles in MEDLINE and PubMed from January 2000 to September 2010. Our results showed that the overall reported prevalence rate of ED in Asia ranged widely, from $2 \%$ to $88 \%$. This finding indicates that ED is a common and major health problem in this region. However, sociocultural and economic factors in Asia prevent people from seeking and obtaining appropriate medical care. We found reports on five kinds of PDE-5 inhibitors for the management of ED: sildenafil, vardenafil, tadalafil, udenafil and mirodenafil. The results of RCTs showed that these five PDE-5 inhibitors are more effective than placebo in improving erectile function in Asian men with ED and that these drugs have similar efficacy and safety profiles.
\end{abstract}

Asian Journal of Andrology (2011) 13,543-549; doi:10.1038/aja.2010.131; published online 4 April 2011

Keywords: Asia; erectile dysfunction; phosphodiesterase inhibitors; prevalence

\section{INTRODUCTION}

Erectile dysfunction (ED) has been defined as the inability to achieve or maintain an erection sufficiently rigid for achieving satisfying sexual intercourse. ${ }^{1}$ ED is an important worldwide health issue that affects nearly half of men over the age of 40 years, and it has a significant negative impact on the quality of life and life satisfaction of the affected individual as well as his partner. ${ }^{2,3}$ One of the most frequently cited epidemiological surveys reporting prevalence data for ED is the Massachusetts Male Aging Study. ${ }^{2}$ The Massachusetts Male Aging Study - the first longitudinal, community-based, randomized, widescale epidemiological study of ED-included 1709 men between the ages of 40 and 70 years who completed a self-reported ED questionnaire. Over that age range, the probabilities of minimal, moderate and complete ED were $16.5 \%, 17.5 \%$ and $4.9 \%$, respectively, at age of 40 years, and $18 \%, 34 \%$ and $15 \%$ at age of 70 years, showing that the prevalence of ED increases with age.

Another pivotal epidemiological study of sexual dysfunction was the Global Study of Sexual Attitudes and Behaviors (GSSAB), which included 27500 men and women aged 40-80 years in 29 countries. ${ }^{4}$ This study showed that physical, social/emotional and relationship factors all have a significant impact on the prevalence of ED.

The incidence of ED is higher in men with diabetes mellitus, hypertension, hypercholesterolemia, atherosclerosis or cardiovascular disease. All of these diseases and conditions are known to be associated with endothelial dysfunction. ${ }^{5,6}$ Men who reported having at least one type of vascular disease were more likely to experience erectile difficulties. ${ }^{4}$ In the Global Better Sex Survey, Asian men and women agreed that sex was an important part of their lives and partner relationships; however, many men may not recognize that ED is a treatable medical condition. ${ }^{7}$

Here we review the prevalence rate of ED in Asia, associated factors that influence sexual attitudes and sexual behaviour, help-seeking patterns, and the clinical efficacy and safety of phosphodiesterase- 5 (PDE-5) inhibitors in Asian men.

\section{PREVALENCE RATE OF ED IN ASIA}

The prevalence of ED in Asian populations was recently analyzed by Cheng et al. $^{8}$ They performed computer-based searches through MEDLINE, PubMed, PsycINFO and other general Internet search engines for articles documenting the prevalence of ED in Asian countries between 1986 and 2006. Among the 219 relevant articles initially identified, 34 articles were retrieved, 18 of which were analyzed as general population studies. The overall reported prevalence rate of ED in Asia ranged widely, from $2 \%$ to $81.8 \% .^{8}$ It was $11 \%$ in Indonesia, $19.5 \%-28.3 \%$ in China, $8 \%-50 \%$ in Hong Kong, $13 \%-81.1 \%$ in Japan, $22.4 \%-59 \%$ in Malaysia, $33 \%-65 \%$ in the Philippines, $2 \%-53 \%$ in Singapore, $18 \%-36.6 \%$ in South Korea, $9 \%-17.7 \%$ in Taiwan (China) and $29 \%-65 \%$ in Thailand. The prevalence of ED increased with age. The pooled random-effects agespecific prevalence rates were $15.1 \%, 29.6 \%, 40.6 \%, 54.3 \%$ and $70.0 \%$ for the age groups $20-29,30-39,40-49,50-59$ and $60-69$ years, respectively. The overall, age-standardized prevalence was $36.8 \%$. This meta-analysis showed that the prevalence rates of ED differed between countries and that there was also a wide range of overall ED prevalence 
in a country. The limitation of this analysis was that the tools used to evaluate ED prevalence were not the same across studies. In addition, even though the International Index of Erectile Function (IIEF) was the most frequently used assessment tool, for some of the studies a validated IIEF was not available in the local language. ${ }^{8}$

We searched for epidemiological studies through MEDLINE and PubMed for the period from 2001 to 2010. We reviewed 20 general population studies of ED in Asian regions (Table 1).$^{9-28}$ Among them, there were three important epidemiological studies of ED in Asian populations: the GSSAB subgroup study in Asian countries, ${ }^{12}$ the Asian Men's Attitudes to Life Events and Sexuality study ${ }^{11}$ and the Asian Survey of Aging Males. ${ }^{15}$ The GSSAB subgroup study compared sexual behaviours, the prevalence of sexual dysfunction and help-seeking patterns in nine Asian countries. In that study, the prevalence of ED was the highest in the Philippines (33\%), followed by Thailand (29\%), Malaysia (28\%), Korea (18\%), Japan (13\%), Taiwan (China) (9\%), Hong Kong (China) (8\%) and Singapore (2\%) (Table 1). The Men's Attitudes to Life Events and Sexuality Phase I study consisted of
10934 men aged 20-75 years from Mainland China, Japan, Korea, Malaysia and Taiwan (China). In that study, the self-reported prevalence of ED was the highest in Japan (14\%) and the lowest in Malaysia $(3 \%) .{ }^{11}$ The Asian Survey of Aging Males survey was conducted in 1155 men aged 50-80 years from Hong Kong (China), Singapore, Malaysia, Philippines and Thailand. ED was reported by $63 \%$ of the participants, via the sexual function using Danish prostate symptom score questionnaire. The prevalence of ED was the highest in the Philippines (65\%) and Thailand (65\%), followed by Malaysia (59\%), Singapore (53\%) and Hong Kong (China) (50\%). For these three studies, as shown in Table 1, the overall reported prevalence rates of ED in Asia ranged widely, from $2 \%$ to $88 \%$. This high prevalence of $\mathrm{ED}$ indicates that $\mathrm{ED}$ is a common health problem in the Asian region.

Most of the other epidemiological studies in Asian regions were based on populations within a country. The majority were reported from East Asia and Southeast Asia because epidemiological data from other Asian countries are not well represented in the international database search engines. The sample sizes, age groups and assessment

Table 1 Prevalence of ED in Asian countries ${ }^{9-28}$

\begin{tabular}{|c|c|c|c|c|c|}
\hline Region & Study & Study size (n) & $\begin{array}{l}\text { Age range } \\
\text { (year) }\end{array}$ & $\begin{array}{c}\text { Range of overall ED } \\
\text { prevalence (\%) }\end{array}$ & Assessment tools \\
\hline \multirow[t]{4}{*}{ Mainland China } & Bai et al..$^{9}$ & 2226 & $20-86$ & $28.4^{\mathrm{a}}$ & Self-report \\
\hline & Lau et al. ${ }^{10}$ & 298 & 20-39 & 19.5 & Self-report \\
\hline & Tan et al. ${ }^{11}$ & 225 & $20-75$ & 6 & Self-report \\
\hline & Nicolosi et al. ${ }^{12}$ & 250 & $40-80$ & 20 & Self-report \\
\hline \multirow[t]{4}{*}{ Hong Kong (China) } & Wong et al. ${ }^{13}$ & 1566 & $65-92$ & 88 & IIEF \\
\hline & Ng et al. ${ }^{14}$ & 1506 & $26-70$ & 36.7 & Self-report \\
\hline & Li et al. ${ }^{15}$ & 201 & $50-80$ & 50 & DAN-PSS-Sex, IIEF \\
\hline & Nicolosi et al. ${ }^{12}$ & 250 & $40-80$ & 8 & Self-report \\
\hline Indonesia & Nicolosi et al. ${ }^{12}$ & 250 & $40-80$ & 11 & Self-report \\
\hline \multirow[t]{5}{*}{ Japan } & Marumo et al. ${ }^{16}$ & 1517 & $23-79$ & $1.0-25.9^{b}$ & IIEF \\
\hline & Sasayama et al. ${ }^{17}$ & 6112 & $30-80$ & 32 & Self-report \\
\hline & Nicolosi et al. ${ }^{18}$ & 600 & $40-70$ & $34^{\mathrm{a}}$ & Self-report \\
\hline & Tan et al. ${ }^{11}$ & 228 & $20-75$ & 14 & Self-report \\
\hline & Nicolosi et al. ${ }^{12}$ & 750 & $40-80$ & 13 & Self-report \\
\hline \multirow[t]{5}{*}{ Korea } & Ahn et al..$^{19}$ & 1570 & $40-79$ & 45.8 & Self-report, IIEF \\
\hline & Cho et al..20 & 3501 & $>20$ & $36.5^{\mathrm{a}}$ & IIEF \\
\hline & Moreira et al. ${ }^{21}$ & 600 & 40-80 & 31.9 & Self-report \\
\hline & Tan et al. ${ }^{11}$ & 225 & $20-75$ & 8 & Self-report \\
\hline & Nicolosi et al. ${ }^{12}$ & 600 & $40-80$ & 18 & Self-report \\
\hline \multirow[t]{5}{*}{ Malaysia } & Khoo et al. ${ }^{22}$ & 351 & $>50$ & 70.1 & IIEF \\
\hline & Quek et al. ${ }^{23}$ & 430 & $>20$ & 41.6 & IIEF \\
\hline & Li et al. ${ }^{15}$ & 250 & 50-80 & 59 & DAN-PSS-Sex, IIEF \\
\hline & Tan et al. ${ }^{11}$ & 380 & $20-75$ & 3 & Self-report \\
\hline & Nicolosi et al. ${ }^{12}$ & 250 & $40-80$ & 28 & Self-report \\
\hline \multirow[t]{2}{*}{ Philippines } & Li et al. ${ }^{15}$ & 250 & $50-80$ & 65 & DAN-PSS-Sex, IIEF \\
\hline & Nicolosi et al. ${ }^{12}$ & 250 & $40-80$ & 33 & Self-report \\
\hline \multirow[t]{3}{*}{ Singapore } & Li et al. ${ }^{15}$ & 204 & $50-80$ & 53 & DAN-PSS-Sex, IIEF \\
\hline & Tan et al. ${ }^{24}$ & 729 & $>30$ & 51.3 & IIEF \\
\hline & Nicolosi et al. ${ }^{12}$ & 250 & $40-80$ & 2 & Self-report \\
\hline \multirow[t]{5}{*}{ Taiwan (China) } & Hwang et al. ${ }^{25}$ & 1060 & $>30$ & 27 & IIEF, EHS, QEQ \\
\hline & Wu et al. ${ }^{26}$ & 990 & $>40$ & 26 & Self-report, IIEF \\
\hline & Chen et al. ${ }^{27}$ & 1002 & $>40$ & 17.7 & Self-report \\
\hline & Tan et al. ${ }^{11}$ & 228 & 20-75 & 4 & Self-report \\
\hline & Nicolosi et al. ${ }^{12}$ & 250 & $40-80$ & 9 & Self-report \\
\hline \multirow[t]{3}{*}{ Thailand } & Permpongkosol et al. ${ }^{28}$ & 2269 & $40-70$ & 42.1 & Self-report \\
\hline & Li et al. ${ }^{15}$ & 250 & $50-80$ & 65 & DAN-PSS-Sex, IIEF \\
\hline & Nicolosi et al. ${ }^{12}$ & 250 & $40-80$ & 29 & Self-report \\
\hline
\end{tabular}

Abbreviations: DAN-PSS-Sex, sexual function using Danish prostate symptom score; ED, erection dysfunction; EHS, erection hardness score; IIEF, International Index of Erectile Function; $Q E Q$, quality of erection questionnaire.

${ }^{\text {a }}$ Age adjusted.

${ }^{\mathrm{b}}$ Prevalence of ED according to age. 
tools for ED were different in each study. The prevalence rate of ED varies according to the definitions and methodologies used in ED research. Therefore, future studies should be considered to collect age-specific, ED severity-specific prevalence data and to adopt an appropriate ED assessment tool with a validated cutoff value.

\section{SEXUAL ATTITUDES AND SEXUAL BEHAVIOUR IN ASIAN MEN}

The GSSAB study showed that most men and women with sexual dysfunction had not consulted a doctor about these problems. ${ }^{12}$ This lack of communication between physician and patient is not unique to Asia; the global study showed that only $9 \%$ of men and women had been asked about their sexual health by a doctor. ${ }^{29}$ Sexual attitudes can be influenced by cultural differences. Asian men are known to be conservative towards sex and less sexually active than Western men. ${ }^{12}$ More specifically, the pattern of treatment-seeking behaviour differs between East and Southeast Asian regions because of cultural and religious influences. In East Asia, a Confucian cultural background predominates, whereas in Southeast Asia, people may have a Buddhist background (Thailand), a Muslim background (Malaysia and Indonesia) or a Catholic background (the Philippines). As one study reported, in Korea and other East Asian countries most patients took no action, whereas in Southeast Asia help was often sought from a partner, a family member or another source of social support ${ }^{12}$ (Figure 1). Another substantial barrier to seeing a physician is the cost. Limited accessibility of medical care for financial reasons was most common in Mainland China, Indonesia and Thailand and least common in Hong Kong (China), Singapore and Japan. ${ }^{12}$ These sociocultural and economic factors appear to prevent people from seeking and obtaining medical care. The findings imply that public awareness of $\mathrm{ED}$ is needed in order to encourage men to consult a physician.

\section{MEDICAL TREATMENT OF ED IN ASIA}

The first-line therapeutic option for the treatment of ED is PDE-5 inhibitors. Five types of PDE-5 inhibitors have been introduced: sildenafil, tadalafil, vardenafil, udenafil and mirodenafil. A systematic review and meta-analysis of data on oral PDE-5 inhibitors was recently reported. ${ }^{30}$ In the 130 randomized clinical trials (RCTs) analyzed, 72 were for sildenafil, 27 were for vardenafil, 28 were for tadalafil, two were for mirodenafil and one was for udenafil. Four RCTs directly compared PDE-5 inhibitors. This study concluded that oral PDE-5 inhibitors improve erectile functioning and have similar efficacy and safety profiles.

In the current review, after a search of MEDLINE and PubMed for articles published from January 2000 to September 2010, we selected 14 Asian RCTs of PDE-5 inhibitors (Table 2). These included four RCTs of sildenafil, ${ }^{31-34}$ two RCTs of vardenafil, ${ }^{35,36}$ four RCTs of tadalafil,${ }^{37-40}$ two RCTs of udenafil ${ }^{41,42}$ and two RCTs of mirodenafill $^{43,44}$ The efficacy and safety of two novel PDE-5 inhibitors, mirodenafil and udenafil, were evaluated only in Korean men. In this review, we did not include clinical trials of PDE-5 inhibitors in men with specific comorbid diseases, such as diabetes, hypertension and other neurovascular diseases.

\section{Efficacy and safety of sildenafil}

Of the five PDE-5 inhibitors, sildenafil was the first to be launched in Asia. Three multinational or multi-institutional studies, collectively called the Asian Sildenafil Efficacy and Safety Study (ASSESS), have evaluated the efficacy, safety and tolerability of oral sildenafil in Asian men with ED with broad-spectrum aetiology. ${ }^{31-33}$ The ASSESS-1 trial was carried out at eight centres in Malaysia, the Philippines and Singapore. ${ }^{31}$ ASSESS-2 was performed in four centres in Thailand ${ }^{32}$ and ASSESS- 3 was conducted in Taiwan (China). ${ }^{33}$ In these three studies, a total of 616 Asian men were randomly assigned to 12 weeks of sildenafil or placebo taken as needed $1 \mathrm{~h}$ before anticipated sexual activity. Initially, the sildenafil or matching placebo dose was $50 \mathrm{mg}$ but could be increased to $100 \mathrm{mg}$ or decreased to $25 \mathrm{mg}$ depending on efficacy or intolerance, respectively. The primary efficacy variables related to achievement and maintenance of erections sufficient

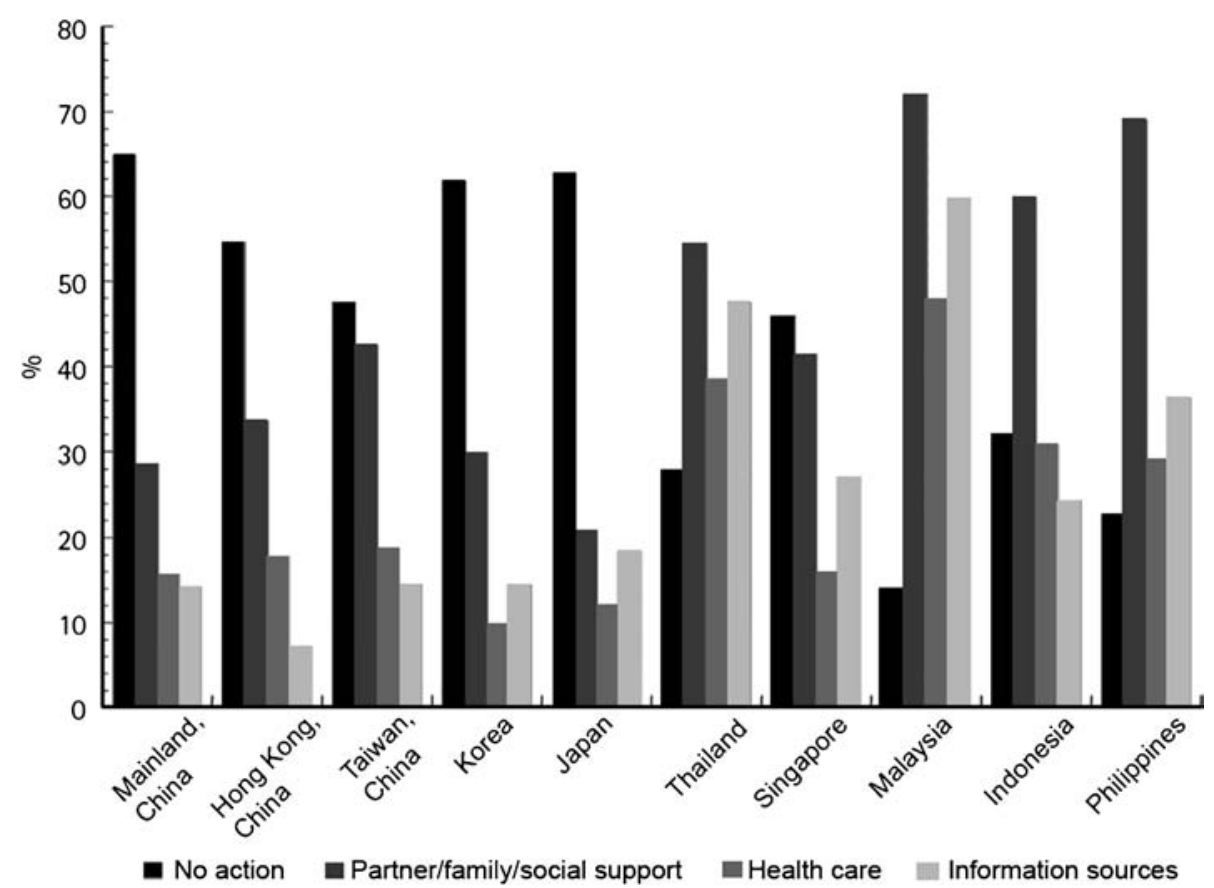

Figure 1 Help-seeking behaviour of men and women with sexual dysfunction in Asia as determined by the GSSAB, 2001-2002. ${ }^{12}$ Adapted with permission. GSSAB, Global Study of Sexual Attitudes and Behaviors. 
Table 2 Studies evaluating PDE-5-I administration for ED in Asian men ${ }^{31-44}$

\begin{tabular}{|c|c|c|c|c|c|c|}
\hline Study & Drug & Study design & Patients & Outcome measures & Efficacy & Adverse event \\
\hline Tan et al..$^{31}$ & $\begin{array}{l}\text { Sildenafil versus placebo } \\
\text { (50 mg increased to } \\
100 \mathrm{mg} \text { or decreased } \\
\text { to } 25 \mathrm{mg} \text { ) for } 12 \text { weeks }\end{array}$ & $\begin{array}{l}\text { Multinational, } \\
\text { multi-institutional } \\
\text { randomized } \\
\text { controlled trial }\end{array}$ & $\begin{array}{l}254 \text { men; } \\
\text { aged } 26-78 \text { years; } \\
\text { ED duration }>6 \\
\quad \text { months }\end{array}$ & $\begin{array}{l}\text { IIEF, patients' event } \\
\text { logs of sexual } \\
\text { activity, and a global } \\
\text { efficacy question }\end{array}$ & $\begin{array}{l}\text { Higher EF with sildenafil } \\
\text { than with placebo, } \\
\text { IIEF Q3 (4.22 } \\
\text { versus 2.59) } \\
\text { and Q4 (4.15 versus } \\
\text { 2.41) }(P<0.0001) \text {, } \\
\text { significantly improved } \\
\text { IIEF-EF and GEAQ } \\
\text { in sildenafil group } \\
(P<0.0001)\end{array}$ & $\begin{array}{l}22.8 \% \text { of sildenafil } \\
\text { versus } 10.2 \% \text { of } \\
\text { placebo; flushing, } \\
\text { dizziness and } \\
\text { headache }\end{array}$ \\
\hline $\begin{array}{c}\text { Kongkanand } \\
\text { et al. }\end{array}$ & $\begin{array}{l}\text { Sildenafil versus placebo } \\
\text { (50 mg increased to } \\
100 \mathrm{mg} \text { or decreased } \\
\text { to } 25 \mathrm{mg} \text { ) for } 12 \text { weeks }\end{array}$ & $\begin{array}{l}\text { Multi-institutional } \\
\text { randomized } \\
\text { controlled trial } \\
\text { in Thailand }\end{array}$ & $\begin{array}{l}125 \text { men; } \\
\text { aged } 26-77 \text { years; } \\
\text { ED duration }>6 \\
\text { months }\end{array}$ & $\begin{array}{l}\text { IIEF, patients' event } \\
\text { logs of sexual } \\
\text { activity, and a global } \\
\text { efficacy question }\end{array}$ & $\begin{array}{l}\text { Higher EF with sildenafil } \\
\text { than with placebo, } \\
\text { successful attempts at } \\
\text { sexual intercourse } \\
(66.16 \% \text { versus } 33.05 \%)\end{array}$ & $\begin{array}{l}30.2 \% \text { of sildenafil } \\
\text { versus } 11.3 \% \text { of } \\
\text { placebo; flushing, } \\
\text { dizziness and } \\
\text { headache }\end{array}$ \\
\hline Choi et al. ${ }^{34}$ & $\begin{array}{l}\text { Sildenafil versus placebo } \\
\text { (50 mg increased to } \\
100 \mathrm{mg} \text { or decreased } \\
\text { to } 25 \mathrm{mg} \text { ) for } 8 \text { weeks }\end{array}$ & $\begin{array}{l}\text { Multi-institutional } \\
\text { randomized } \\
\text { controlled trial } \\
\text { in Korea }\end{array}$ & $\begin{array}{l}133 \text { men; } \\
\text { aged 28-78 years; } \\
\text { ED duration }>6 \\
\quad \text { months }\end{array}$ & $\begin{array}{l}\text { IIEF, patients' event } \\
\text { logs of sexual } \\
\text { activity, and a global } \\
\text { efficacy question }\end{array}$ & $\begin{array}{l}\text { Higher EF with sildenafil than } \\
\text { with placebo, IIEF Q3 (4.19 } \\
\text { versus } 2.67) \text { and Q4 (3.74 } \\
\text { versus } 2.07)(P<0.0001) \text {, } \\
\text { significantly improved } \\
\text { IIEF-EF and GEAQ in } \\
\text { sildenafil group ( } P<0.0001)\end{array}$ & $\begin{array}{l}56.1 \% \text { of sildenafil } \\
\text { versus } 20.9 \% \text { of } \\
\text { placebo; flushing, } \\
\text { headache and } \\
\text { abnormalities in } \\
\text { colour vision }\end{array}$ \\
\hline Tan et al..$^{35}$ & $\begin{array}{l}\text { Vardenafil (10 mg) } \\
\text { versus placebo for } \\
12 \text { weeks }\end{array}$ & $\begin{array}{l}\text { Multinational, } \\
\text { multi-institutional } \\
\text { randomized } \\
\text { controlled trial }\end{array}$ & $\begin{array}{l}358 \text { men; } \\
\text { aged } \geqslant 20 \text { years; } \\
\text { ED duration }>6 \\
\quad \text { months }\end{array}$ & $\begin{array}{l}\text { IIEF-EF domain score, } \\
\text { success rate of } \\
\text { vaginal penetration } \\
\text { (SEP2), penile } \\
\text { rigidity (SEP3), GAQ }\end{array}$ & $\begin{array}{l}\text { Increased IIEF-EF scores in } \\
\text { vardenafil compared with } \\
\text { placebo (22.4 versus } 14.3 \text {, } \\
P<0.001) \text {, improved SEP2 } \\
\text { (82.2 versus } 43.6 \text {, } \\
P<0.001), \text { SEP3 (66.1 } \\
\text { versus } 24.0, P<0.001) \text {, } \\
\text { positive GAQ responses } \\
\text { (81.8\% versus } 24.3 \%)\end{array}$ & $\begin{array}{l}25.4 \% \text { of the } \\
\text { vardenafil group, the } \\
\text { majority mild and } \\
\text { transient headache, } \\
\text { flushing, nasal } \\
\text { congestion and } \\
\text { dizziness }\end{array}$ \\
\hline Yip et al. ${ }^{37}$ & $\begin{array}{l}\text { Tadalafil (20 mg) } \\
\text { versus placebo } \\
\text { for } 12 \text { weeks }\end{array}$ & $\begin{array}{l}\text { Multinational, } \\
\text { multi-institutional } \\
\text { randomized } \\
\text { controlled trial }\end{array}$ & $\begin{array}{l}242 \text { men; } \\
\text { aged }>18 \text { years; } \\
\text { ED duration }>3 \\
\quad \text { months }\end{array}$ & $\begin{array}{l}\text { IIEF, } \\
\text { SEP diary, } \\
\text { GAQ }\end{array}$ & $\begin{array}{l}\text { Significantly improved EF } \\
\text { in tadalafil compared with } \\
\text { placebo }(P<0.001) \\
\text { greater SEP3 }(70.9 \% \\
\text { versus } 33.5 \%) \text {, greater } \\
\text { GAQ }(86.2 \% \text { versus } 30.1 \%)\end{array}$ & $\begin{array}{l}\text { Headache }(11.3 \%), \\
\text { back pain }(7.5 \%), \\
\text { dizziness }(3.8 \%) \\
\text { and dyspepsia } \\
(3.1 \%)\end{array}$ \\
\hline Guo et al. ${ }^{38}$ & $\begin{array}{l}\text { Tadalafil (10 or } \\
20 \text { mg) versus } \\
\text { placebo for } \\
12 \text { weeks }\end{array}$ & $\begin{array}{l}\text { Multinational, } \\
\text { multi-institutional } \\
\text { randomized } \\
\text { controlled trial }\end{array}$ & $\begin{array}{l}367 \text { men; } \\
\text { aged }>18 \text { years; } \\
(>21 \text { in Singapore) } \\
\text { ED duration }>3 \\
\quad \text { month }\end{array}$ & $\begin{array}{l}\text { IIEF, } \\
\text { SEP diary, } \\
\text { GAQ }\end{array}$ & $\begin{array}{l}\text { Tadalafil } 10 \text { and } 20 \mathrm{mg} \text { improve } \\
\text { IIEF ( } 8.1 \text { and } 8.7 \text {, versus } \\
\text { placebo } 2.4, P<0.001 \text { ), } \\
\text { SEP3 }(62 \% \text { and } 70 \% \text {, } \\
\text { placebo } 32 \%, P<0.001 \text { ), } \\
\text { GAQ }(81 \% \text { and } 86 \% \\
\text { versus } 44 \%, P<0.001 \text { ) }\end{array}$ & $\begin{array}{l}\text { Headache, back pain, } \\
\text { dyspepsia and } \\
\text { dizziness }\end{array}$ \\
\hline
\end{tabular}


Table 2 (Continued) Studies evaluating PDE-5-I administration for ED in Asian men ${ }^{31-44}$

\begin{tabular}{|c|c|c|c|c|c|c|}
\hline Study & Drug & Study design & Patients & Outcome measures & Efficacy & Adverse event \\
\hline Chen et al. ${ }^{39}$ & $\begin{array}{l}\text { Tadalafil (10 or } \\
20 \mathrm{mg} \text { ) versus } \\
\text { placebo for } 12 \text { weeks }\end{array}$ & $\begin{array}{l}\text { Multi-institutional } \\
\text { randomized } \\
\text { controlled trial } \\
\text { in Taiwan }\end{array}$ & $\begin{array}{l}196 \text { men; } \\
\text { aged }>21 \text { years; } \\
\text { ED duration }>3 \\
\quad \text { months }\end{array}$ & $\begin{array}{l}\text { IIEF, } \\
\text { SEP diary, } \\
\text { GAQ }\end{array}$ & $\begin{array}{l}\text { Tadalafil improved EF } \\
\text { compared with placebo } \\
\text { ( } P<0.005) \text {, SEP Q3: } \\
\text { 70.0\%, } 10 \text { mg; } 78.0 \%, 20 \mathrm{mg} \\
\text { versus } 42.8 \% \text { placebo, } \\
\text { GAQ: } 92.3 \% \text { and } 84.6 \% \\
\text { versus } 54.5 \% \text { placebo }\end{array}$ & $\begin{array}{l}\text { Back pain, } \\
\text { dyspepsia and } \\
\text { myalgia }\end{array}$ \\
\hline Guo et al. ${ }^{40}$ & $\begin{array}{l}\text { Tadalafil (10 or } \\
20 \mathrm{mg} \text { ) versus } \\
\text { placebo for } 12 \text { weeks }\end{array}$ & $\begin{array}{l}\text { Integrated analysis } \\
\text { of five double- } \\
\text { blind, placebo- } \\
\text { controlled trials }\end{array}$ & $\begin{array}{l}1046 \text { men; } \\
\text { aged }>18 \text { years; } \\
\text { ED duration }>3 \\
\quad \text { months }\end{array}$ & $\begin{array}{l}\text { IIEF, } \\
\text { SEP diary, } \\
\text { GAQ }\end{array}$ & $\begin{array}{l}\text { Tadalafil } 10 \text { or } 20 \text { mg improved } \\
\text { IIEF-EF }(P<0.001) \text {, better } \\
\text { SEP Q3 }(64.1 \%, 70.5 \% \\
\text { versus placebo } 33.4 \%, \\
P<0.001) \text {, improved GAQ } \\
(85.5 \%, 85.4 \% \text { versus } \\
\text { placebo } 43.5 \%, P<0.001)\end{array}$ & $\begin{array}{l}1.3 \% \text { of tadalafil } \\
\text { versus } 1.1 \% \\
\text { of placebo; } \\
\text { headache and } \\
\text { back pain }\end{array}$ \\
\hline Paick et al. ${ }^{41}$ & $\begin{array}{l}\text { Udenafil (100 or } \\
200 \mathrm{mg} \text { ) versus } \\
\text { placebo for } 12 \text { weeks }\end{array}$ & $\begin{array}{l}\text { Multi-institutional } \\
\text { randomized } \\
\text { controlled trial } \\
\text { in Korea }\end{array}$ & $\begin{array}{l}167 \text { men; } \\
\text { aged } 19-70 \text { years; } \\
\text { ED duration }>6 \\
\quad \text { months }\end{array}$ & $\begin{array}{l}\text { IIEF, SEP } \\
\text { diary, GAQ }\end{array}$ & $\begin{array}{l}\text { Significantly improved IIEF- } \\
\text { EF, SEP Q2 and SEP Q3 } \\
(P<0.0001), \mathrm{GAQ} \text { (placebo, } \\
\text { 25.9\%; udenafil } 100 \mathrm{mg} \\
\text { 81.5\%; udenafil } 200 \mathrm{mg} \\
\text { 88.5\%, } P<0.0001 \text { ) }\end{array}$ & $\begin{array}{l}\text { Flushing, headache } \\
\text { and nasal } \\
\text { congestion }\end{array}$ \\
\hline Park et al. ${ }^{42}$ & $\begin{array}{l}\text { Udenafil (100 mg) } \\
\text { versus placebo } \\
\text { for } 4 \text { weeks }\end{array}$ & $\begin{array}{l}\text { Multi-institutional } \\
\text { randomized } \\
\text { controlled trial } \\
\text { in Korea }\end{array}$ & $\begin{array}{l}103 \text { men; } \\
\text { aged } 19-70 \text { years; } \\
\text { ED duration }>6 \\
\quad \text { months }\end{array}$ & $\begin{array}{l}\text { IIEF-EF domain score, } \\
\text { SEP2, SEP3 }\end{array}$ & $\begin{array}{l}\text { Enhanced SEP Q3 (placebo, } \\
\text { 28.3\% versus udenafil, } \\
\text { 54.7\%; } P<0.0001 \text { ), } \\
\text { significant change from } \\
\text { base line in IIEF-EF } \\
\text { (placebo, } 0.58 \text {; udenafil, } \\
\text { 4.40; } P<0.0001 \text { ) }\end{array}$ & $\begin{array}{l}4 \% \text { of placebo, } \\
11.3 \% \text { of udenafil; } \\
\text { flushing, headache } \\
\text { and toothache }\end{array}$ \\
\hline Paick et al. ${ }^{43}$ & $\begin{array}{l}\text { Mirodenafil (SK3530; 50, } \\
100 \text { or } 150 \text { mg) versus } \\
\text { placebo for } 8 \text { weeks }\end{array}$ & $\begin{array}{l}\text { Multi-institutional } \\
\text { randomized } \\
\text { controlled trial } \\
\text { in Korea }\end{array}$ & $\begin{array}{l}119 \text { men; } \\
\text { aged } 19-70 \text { years; } \\
\text { ED duration }>6 \\
\quad \text { months }\end{array}$ & $\begin{array}{l}\text { IIEF, SEP } \\
\text { diary, GAQ }\end{array}$ & $\begin{array}{l}\text { All primary and secondary } \\
\text { efficacy end points } \\
\text { significantly improved } \\
(P<0.05) 42.3 \% \text { achieved } \\
\text { normal erectile function } \\
\text { after treatment }\end{array}$ & $\begin{array}{l}\text { Flushing, headache, } \\
\text { dizziness and eye } \\
\text { redness ( } 10.9 \%, \\
7.6 \%, 2.5 \% \text { and } \\
2.5 \%, \text { respectively) }\end{array}$ \\
\hline Paick et al..44 & $\begin{array}{l}\text { Mirodenafil (50 or } \\
100 \mathrm{mg} \text { ) versus } \\
\text { placebo for } 12 \text { weeks }\end{array}$ & $\begin{array}{l}\text { Multi-institutional } \\
\text { randomized } \\
\text { controlled trial in } \\
\text { Korea }\end{array}$ & $\begin{array}{l}223 \text { men; } \\
\text { aged } 19-70 \text { years; } \\
\text { ED duration }>6 \\
\quad \text { months }\end{array}$ & $\begin{array}{l}\text { IIEF, SEP diary, } \\
\text { GAQ, LSC }\end{array}$ & $\begin{array}{l}\text { Mirodenafil } 50 \text { and } 100 \text { mg, } \\
\text { greater increase in IIEF Q3, } \\
\text { Q4 }(P<0.0001) \text {, improved } \\
\text { IIEF-EF, SEP2, SEP3, GAQ } \\
\text { and LSC }\end{array}$ & $\begin{array}{l}\text { Mild intensity flushing, } \\
\text { headache, nausea } \\
\text { and eye redness }\end{array}$ \\
\hline
\end{tabular}

Abbreviations: ED, erectile dysfunction; EF, erectile function; IIEF, International Index of Erectile Function; GAQ, global assessment question; GEAP, global efficacy assessment question; LSC, life satisfaction checklist; PDE-5, phosphodiesterase-5; SEP, sexual encounter profile.

for sexual intercourse and the secondary efficacy variables, such as IIEF-EF domains, the percentage of successful intercourse attempts and the global assessment of erections, were all statistically significantly improved by sildenafil as compared with placebo. In one trial, only the sexual-desire domain showed no significant difference. ${ }^{32}$ These results demonstrate that sildenafil is effective in restoring sexual function in Asian men with ED of various aetiologies. The other RCT of sildenafil, the ASSESS-K study, was a flexibledose escalation study performed at six centres in Korea. ${ }^{34}$ ASSESS-K was similar to the other ASSESS studies except for a shorter trial period ( 8 weeks). In all four studies, common adverse events with sildenafil were flushing, dizziness and headache, most of which were mild.

\section{Efficacy and safety of vardenafil}

Two prospective, randomized, double-blind, placebo-controlled, fixed-dose, parallel-group studies have been conducted to assess the safety and efficacy of vardenafil $10 \mathrm{mg}$ for the treatment of ED in Asian regions. ${ }^{35,36}$ The first such study was performed in six countries or regions: Malaysia, Singapore, Thailand, the Philippines, Hong Kong (China) and Indonesia. ${ }^{35}$ In this study, 358 men with ED were randomly assigned to receive vardenafil $10 \mathrm{mg}$ or placebo for 12 weeks. The primary efficacy variables were the IIEF-EF and the sexual encounter profile (SEP) questions related to penetration (SEP2) and intercourse completion (SEP3). Secondary efficacy variables were the global assessment question (GAQ) regarding erection improvement.

Treatment with vardenafil significantly improved the IIEF-EF domain scores as compared with placebo (22.4 versus 14.3; $P<0.001$ ) and also improved SEP2 (vardenafil 82.2 versus placebo 43.6; $P<0.001$ ) and SEP3 (vardenafil 66.1 versus placebo 24.0; $P<0.001)$. Positive GAQ responses were reported by $81.8 \%$ of the participants in the vardenafil group and $24.3 \%$ of those in the placebo group. The most frequent adverse events were headache, flushing, nasal congestion and dizziness.

The other vardenafil study was conducted in 306 men with ED in Taiwan, South Korea and Japan. ${ }^{36}$ Treatment with vardenafil produced significant improvement in the main efficacy measures of IIEF-EF score and SEP2 and SEP3 as well as the GAQ. The efficacy 
and safety of vardenafil in East Asian men were similar to those reported in previous studies of Western populations. ${ }^{45,46}$

\section{Efficacy and safety of tadalafil}

Tadalafil is considered an effective, well-tolerated therapy for Asian men with ED of broad-spectrum severity and aetiology. ${ }^{37-40,47}$ Yip et $a .^{37}$ assessed the efficacy and safety of tadalafil as compared with a placebo in a multicentre, randomized, double-blind, parallel-group, placebo-controlled study conducted at 17 centres across East and Southeast Asia: Hong Kong (China) (one site, 38 patients), Indonesia (two sites, 21 patients), Malaysia (three sites, 32 patients), the Philippines (four sites, 40 patients), Singapore (three sites, 30 patients) and Taiwan (China) (four sites, 81 patients). In this study, men older than 18 years with mild to severe ED of various aetiologies were randomly assigned to receive a placebo or $20 \mathrm{mg}$ tadalafil taken as needed. Tadalafil significantly improved erectile function as compared with placebo $(P<0.001)$. At the end point, the tadalafil group reported successful intercourse attempts (SEP3: 70.9\% compared with 33.5\% in the placebo) and improved erections (GAQ: $86.2 \%$ compared with $30.1 \%)$. The most common treatment-emergent adverse events were headache, back pain, dizziness and dyspepsia.

Tadalafil was also shown to be an effective and well-tolerated treatment for Southeast Asian men with ED. ${ }^{38,39}$ In these studies, the study design was a randomized, double-blind, placebo-controlled study of men with mild to severe ED of various aetiologies who were randomly assigned to receive placebo, tadalafil $10 \mathrm{mg}$ or tadalafil $20 \mathrm{mg}$ taken as needed without restrictions on food intake and timing of sexual activity for 12 weeks. Tadalafil RCTs were conducted in 10 centres across Mainland China, Singapore and the Philippines ${ }^{38}(n=367)$ and eight centres in Taiwan (China) ${ }^{39}$ $(n=196)$. Compared with placebo, tadalafil significantly improved erectile dysfunction on all efficacy outcomes $(P<0.001)$. The most common adverse events reported by patients were headache, back pain, dyspepsia and dizziness.

Guo et al. ${ }^{40}$ conducted an integrated analysis of five Asian tadalafil clinical trials involving 1046 patients and determined the efficacy and safety of tadalafil in diverse clinical populations with comorbid medical conditions. In this study, patients receiving $10 \mathrm{mg}$ or $20 \mathrm{mg}$ tadalafil, as compared with patients receiving placebo, showed significant improvement from baseline to the end point in the IIEF-EF domain score in all clinical subpopulations $(P<0.001)$. The $10 \mathrm{mg}$ and $20 \mathrm{mg}$ tadalafil groups showed mean success rates of $64.1 \%$ and $70.5 \%$, respectively, for SEP3, as compared with $33.4 \%$ in the placebo group $(P<0.001)$. Also, $85.5 \%$ and $85.4 \%$, respectively, reported improved erections on the end point GAQ versus $43.5 \%$ in the placebo group $(P<0.001)$. Tadalafil was well tolerated across all groups, and the most frequently reported adverse events were headache and back pain.

\section{Efficacy and safety of udenafil}

Udenafil (Zydena ${ }^{\circledR}$, Dong-A Phamaceutical, Seoul, Korea) is a newly developed, potent, selective PDE-5 inhibitor that can also inhibit cyclic guanosine monophosphate hydrolysis. ${ }^{48}$ Its pharmacokinetic profile includes unique clinical properties of both a relatively rapid onset and a long duration of action. ${ }^{49}$ In addition, the isoenzyme selectivity profile of udenafil is similar to that of sildenafil. On the other hand, unlike tadalafil, it does not inhibit PDE-11. In a multicentre, doubleblind, placebo-controlled, fixed-dose, parallel-group phase III trial, 167 Korean patients with ED of diverse origin and severity were randomly assigned to take placebo or udenafil at fixed doses of $100 \mathrm{mg}$ or
$200 \mathrm{mg}$ as needed for 12 weeks. ${ }^{41}$ The efficacy of udenafil was assessed by IIEF-EF domain scores, SEP2, SEP3 and GAQ. The patients treated with udenafil showed a significantly greater change from baseline in the IIEF-EF domain score as compared with those given placebo (placebo, 0.20; $100 \mathrm{mg}$ udenafil, 7.52; and $200 \mathrm{mg}$ udenafil, 9.93) $(P<0.0001)$. Udenafil significantly enhanced SEP2 and SEP3 as compared with placebo $(P<0.0001)$. The GAQ also increased significantly in the udenafil group as compared with the placebo group (GAQ: $100 \mathrm{mg}$ udenafil, $81.5 \%$; $200 \mathrm{mg}$ udenafil, $88.5 \%$; and placebo, $25.9 \%)(P<0.0001)$. These results indicate that udenafil is an effective and well-tolerated therapy for ED of broad-spectrum aetiology and severity. The most common treatment-related adverse events were facial flushing and headache.

Another RCT evaluated the efficacy of udenafil in treating ED for up to $12 \mathrm{~h}$ after dosing. ${ }^{42}$ This study was performed to evaluate the duration of udenafil efficacy for sexual intercourse. Udenafil significantly enhanced the SEP3 (placebo $28.3 \%$ versus udenafil 54.7\%; $P<0.0001$ ) and IIEF-EF domain from baseline, whereas there was no significant difference in the SEP2 between the two groups. These data suggest that udenafil may be a reliable treatment option in patients who have relatively spontaneous and unscheduled sexual intercourse.

\section{Efficacy and safety of mirodenafil}

Mirodenafil (SK3530) is a newly developed oral PDE-5 inhibitor for the treatment of ED. ${ }^{43}$ Preclinical studies revealed that SK3530 has selectivity comparable with that of conventional PDE-5 inhibitors. ${ }^{43,50}$ Paick et al. ${ }^{43}$ evaluated the efficacy and safety of mirodenafil in a total of 119 patients randomized at 10 centres in Korea. The patients received either mirodenafil (50, 100 or $150 \mathrm{mg}$ ) or placebo for an 8-week period. The efficacy of mirodenafil was assessed using the IIEF, SEP and GAQ. At the end of the study, all primary and secondary efficacy end points were statistically significantly improved by mirodenafil as compared with placebo $(P<0.05)$. The most common adverse events were flushing, headache, dizziness and redness of the eyes (10.9\%, 7.6\%, 2.5\% and $2.5 \%$, respectively), and most were mild.

A consecutive clinical study of mirodenafil was conducted with 223 subjects who were randomly assigned to placebo or mirodenafil at fixed doses of 50 or $100 \mathrm{mg}$ for 12 weeks. ${ }^{44}$ The mirodenafil 50 and $100 \mathrm{mg}$ groups showed a significantly greater increase in the scores for IIEF question 3 regarding the availability of penile penetration to partner ( $P=0.0001$ and $P<0.0001$, respectively) and question 4 (both $P<0.0001)$ at the end point as compared with the placebo group. Mirodenafil in both doses significantly improved the IIEF, SEP2 and SEP3 scores and the GAQ as compared with placebo. The most frequent adverse events were facial flushing, headache, nausea and redness of the eyes.

\section{CONCLUSION}

The prevalence rate of ED in Asia ranged widely, from $2 \%$ to $88 \%$. This finding indicates that ED is a common and major health problem in this region. However, sociocultural and economic factors in Asia prevent people from seeking and obtaining appropriate medical care. Five kinds of PDE-5 inhibitors for the treatment of ED have been studied in Asian countries: sildenafil, vardenafil, tadalafil, udenafil and mirodenafil. The results of RCTs have shown that these five PDE-5 inhibitors are more effective than placebo in improving erectile function in Asian men with ED. The adverse events reported by patients tended to be mild or moderate in severity, and the rate of discontinuation caused by 
adverse events was similar to those observed in Western countries. Further well-designed, long-term PDE-5 inhibitor trials are needed to evaluate their efficacy and safety in the presence of comorbid conditions or specific causes of ED.

\section{COMPETING FINANCIAL INTERESTS}

The authors declare no competing financial interests.

1 NIH Consensus Conference. Impotence. NIH Consensus Development Panel on Impotence. JAMA 1993; 270: 83-90.

2 Feldman HA, Goldstein I, Hatzichristou DG, Krane RJ, McKinlay JB. Impotence and its medical and psychosocial correlates: results of the Massachusetts Male Aging Study. J Urol 1994; 151: 54-61.

3 Nehra A, Kulaksizoglu H. Global perspectives and controversies in the epidemiology of male erectile dysfunction. Curr Opin Urol 2002; 12: 493-6.

4 Laumann EO, Nicolosi A, Glasser DB, Paik A, Gingell C et al. Sexual problems among women and men aged 40-80 y: prevalence and correlates identified in the Global Study of Sexual Attitudes and Behaviors. Int J Impot Res 2005; 17: 39-57.

5 Maas R, Schwedhelm E, Albsmeier J, Boger RH. The pathophysiology of erectile dysfunction related to endothelial dysfunction and mediators of vascular function. Vasc Med 2002; 7: 213-25.

6 Feldman HA, Johannes CB, Derby CA, Kleinman KP, Mohr BA et al. Erectile dysfunction and coronary risk factors: prospective results from the Massachusetts male aging study. Prev Med 2000; 30: 328-38.

7 Tan HM, Marumo K, Yang DY, Hwang TI, Ong ML. Sex among Asian men and women: the Global Better Sex Survey in Asia. Int J Urol 2009; 16: 507-14.

8 Cheng JY, Ng EM, Chen RY, Ko JS. Prevalence of erectile dysfunction in Asian populations: a meta-analysis. Int J Impot Res 2007; 19: 229-44.

9 Bai $Q, X u Q Q$, Jiang $\mathrm{H}$, Zhang WL, Wang XH et al. Prevalence and risk factors of erectile dysfunction in three cities of China: a community-based study. Asian J Androl 2004 6: 343-8.

10 Lau JT, Wang Q, Cheng Y, Yang X. Prevalence and risk factors of sexual dysfunction among younger married men in a rural area in China. Urology 2005; 66: 616-22.

11 Tan HM, Low WY, Ng CJ, Chen KK, Sugita M et al. Prevalence and correlates of erectile dysfunction (ED) and treatment seeking for ED in Asian men: the Asian Men's Attitudes to Life Events and Sexuality (MALES) study. J Sex Med 2007; 4: 1582-92.

12 Nicolosi A, Glasser DB, Kim SC, Marumo K, Laumann EO. Sexual behaviour and dysfunction and help-seeking patterns in adults aged 40-80 years in the urban population of Asian countries. BJU Int 2005; 95: 609-14.

13 Wong SY, Leung JC, Woo J. Sexual activity, erectile dysfunction and their correlates among 1,566 older Chinese men in Southern China. J Sex Med 2009; 6: 74-80.

$14 \mathrm{NgEM}$, Cheng JY. Prevalence and biopsychosocial correlates of erectile dysfunction in Hong Kong: a population-based study. Urology 2007; 70: 131-6.

15 Li MK, Garcia LA, Rosen R. Lower urinary tract symptoms and male sexual dysfunction in Asia: a survey of ageing men from five Asian countries. BJU Int 2005; 96: 1339-54.

16 Marumo K, Nakashima J, Murai M. Age-related prevalence of erectile dysfunction in Japan: assessment by the International Index of Erectile Function. Int J Urol 2001; 8: 53-9.

17 Sasayama S, Ishii N, Ishikura F, Kamijima G, Ogawa S et al. Men's health study: current status of erectile dysfunction of 6,112 ambulatory patients at general practitioners offices in Japan. J Cardiol 2003; 42: 57-65. Japanese.

18 Nicolosi A, Moreira ED Jr, Shirai M, Bin Mohd Tambi MI, Glasser DB. Epidemiology of erectile dysfunction in four countries: cross-national study of the prevalence and correlates of erectile dysfunction. Urology 2003; 61: 201-6.

19 Ahn TY, Park JK, Lee SW, Hong JH, Park NC et al. Prevalence and risk factors for erectile dysfunction in Korean men: results of an epidemiological study. J Sex Med 2007; 4: 1269-76.

20 Cho BL, Kim YS, Choi YS, Hong MH, Seo HG et al. Prevalence and risk factors for erectile dysfunction in primary care: results of a Korean study. Int J Impot Res 2003; 15: 323-8.

21 Moreira ED Jr, Kim SC, Glasser D, Gingell C. Sexual activity, prevalence of sexual problems, and associated help-seeking patterns in men and women aged 40-80 years in Korea: data from the Global Study of Sexual Attitudes and Behaviors (GSSAB). J Sex Med 2006; 3: 201-11.

22 Khoo EM, Tan HM, Low WY. Erectile dysfunction and comorbidities in aging men: an urban cross-sectional study in Malaysia. J Sex Med 2008; 5: 2925-34.

23 Quek KF, Sallam AA, Ng CH, Chua CB. Prevalence of sexual problems and its association with social, psychological and physical factors among men in a Malaysian population: a cross-sectional study. J Sex Med 2008; 5: 70-6.

24 Tan JK, Hong CY, Png DJ, Liew LC, Wong ML. Erectile dysfunction in Singapore: prevalence and its associated factors-a population-based study. Singapore Med $\mathrm{J}$ 2003; 44: 20-6.

25 Hwang TI, Tsai TF, Lin YC, Chiang HS, Chang LS. A survey of erectile dysfunction in Taiwan: use of the Erection Hardness Score and Quality of Erection Questionnaire. J Sex Med 2010; 7: 2817-24.

26 Wu CJ, Hsieh JT, Lin JS, Hwang TI, Jiann BP et al. Comparison of prevalence between self-reported erectile dysfunction and erectile dysfunction as defined by five-item
International Index of Erectile Function in Taiwanese men older than 40 years. Urology 2007; 69: 743-7.

27 Chen KK, Chiang HS, Jiann BP, Lin JS, Liu WJ et al. Prevalence of erectile dysfunction and impacts on sexual activity and self-reported intercourse satisfaction in men older than 40 years in Taiwan. Int J Impot Res 2004; 16: 249-55.

28 Permpongkosol S, Kongkakand A, Ratana-Olarn K, Tantiwong A, Tantiwongse K. Increased prevalence of erectile dysfunction (ED): results of the second epidemiological study on sexual activity and prevalence of ED in Thai males. Aging Male 2008; 11: 128-33.

29 Moreira ED Jr, Brock G, Glasser DB, Nicolosi A, Laumann EO et al. Help-seeking behaviour for sexual problems: the global study of sexual attitudes and behaviors. Int J Clin Pract 2005; 59: 6-16.

30 Tsertsvadze A, Fink HA, Yazdi F, MacDonald R, Bella AJ et al. Oral phosphodiesterase 5 inhibitors and hormonal treatments for erectile dysfunction: a systematic review and meta-analysis. Ann Intern Med 2009; 151: 650-61.

31 Tan HM, Moh CL, Mendoza JB, Gana T, Albano GJ et al. Asian sildenafil efficacy and safety study (ASSESS-1): a double-blind, placebo-controlled, flexible-dose study of oral sildenafil in Malaysian, Singaporean, and Filipino men with erectile dysfunction. The Assess-1 Study Group. Urology 2000; 56: 635-40.

32 Kongkanand A, Ratana-Olarn K, Ruangdilokrat S, Tantiwong A. The efficacy and safety of oral sildenafil in Thai men with erectile dysfunction: a randomized double-blind, placebo controlled, flexible-dose study. J Med Assoc Thai 2003; 86: 195-205

33 Chen KK, Hsieh JT, Huang ST, Jiaan DB, Lin JS et al. ASSESS-3: a randomised, double-blind, flexible-dose clinical trial of the efficacy and safety of oral sildenafi in the treatment of men with erectile dysfunction in Taiwan. Int J Impot Res 2001; 13: 221-9.

34 Choi HK, Ahn TY, Kim JJ, Kim SC, Paick JS et al. A double-blind, randomisedplacebo, controlled, parallel group, multicentre, flexible-dose escalation study to assess the efficacy and safety of sildenafil administered as required to male outpatients with erectile dysfunction in Korea. Int J Impot Res 2003; 15: 80-6.

35 Tan HM, Chin CM, Chua CB, Gatchalian E, Kongkanand A et al. Efficacy and tolerability of vardenafil in Asian men with erectile dysfunction. Asian J Androl 2008; 10: 495-502

36 Chen KK, Paick JS, Ishii N. The efficacy and safety of vardenafil in East Asian men with erectile dysfunction. J Sex Med 2007; 4: 753-61.

37 Yip WC, Chiang HS, Mendoza JB, Tan HM, Li MK et al. Efficacy and safety of on demand tadalafil in the treatment of East and Southeast Asian men with erectile dysfunction: a randomized double-blind, parallel, placebo-controlled clinical study. Asian J Androl 2006; 8: 685-92.

38 Guo YL, Zhu JC, Pan TM, Ding Q, Wang YX et al. Efficacy and safety of on-demand tadalafil for the treatment of erectile dysfunction in South-East Asian men. Int J Urol 2006; 13: 721-7.

39 Chen KK, Jiann BP, Lin JS, Lee SS, Huang ST et al. Efficacy and safety of on-demand oral tadalafil in the treatment of men with erectile dysfunction in Taiwan: a randomized, double-blind, parallel, placebo-controlled clinical study. J Sex Med 2004; 1: 201-8.

40 Guo YL, Viswanathan VP, Chiang HS, Choi HK, Yip AW et al. Efficacy and safety of tadalafil taken as needed for the treatment of erectile dysfunction in Asian men: results of an integrated analysis. Asian J Androl 2009; 11: 423-33.

41 Paick JS, Kim SW, Yang DY, Kim JJ, Lee SW et al. The efficacy and safety of udenafil, a new selective phosphodiesterase type 5 inhibitor, in patients with erectile dysfunction. J Sex Med 2008; 5: 946-53.

42 Park HJ, Park JK, Park K, Min K, Park NC. Efficacy of udenafil for the treatment of erectile dysfunction up to 12 hours after dosing: a randomized placebo-controlled trial. J Sex Med 2010; 7: 2209-16.

43 Paick JS, Choi HK, Kim SC, Ahn TY, Kim JJ et al. Efficacy and safety of oral SK3530 for the treatment of erectile dysfunction in Korean men: a multicenter, randomized, double-blind, placebo-controlled, fixed dose, parallel group clinical trial. Asian $J$ Androl 2008; 10: 791-8.

44 Paick JS, Ahn TY, Choi HK, Chung WS, Kim JJ et al. Efficacy and safety of mirodenafil, a new oral phosphodiesterase type 5 inhibitor, for treatment of erectile dysfunction. J Sex Med 2008; 5: 2672-80

45 Porst H, Rosen R, Padma-Nathan H, Goldstein I, Giuliano F et al. The efficacy and tolerability of vardenafil, a new, oral, selective phosphodiesterase type 5 inhibitor, in patients with erectile dysfunction: the first at-home clinical trial. Int J Impot Res 2001; 13: 192-9.

46 Hellstrom WJ, Gittelman M, Karlin G, Segerson T, Thibonnier M et al Sustained efficacy and tolerability of vardenafil, a highly potent selective phosphodiesterase type 5 inhibitor, in men with erectile dysfunction: results of a randomized, doubleblind, 26-week placebo-controlled pivotal trial. Urology 2003; 61: 8-14.

47 Choi HK, Kim JJ, Kim SC, Suh J, Park YK et al. A randomised, double-blind, parallel, placebo-controlled study of the efficacy and safety of tadalafil administered on demand to men with rectile dysfunction in Korea. Korean J Urol 2006; 47: 852-58.

48 Doh H, Shin CY, Son M, Ko Jl, Yoo M et al. Mechanism of erectogenic effect of the selective phosphodiesterase type 5 inhibitor, DA-8159. Arch Pharm Res 2002; 25: 873-8.

49 Salem EA, Kendirci M, Hellstrom WJ. Udenafil, a long-acting PDE5 inhibitor for erectile dysfunction. Curr Opin Investig Drugs 2006; 7: 661-9.

50 Lee J, Yoo HH, Rhim KJ, Sohn DR, Kim DH. Metabolism and excretion of 5 ethyl-2-\{5-[4-(2-hydroxyethyl)piperazine-1-sulfonyl]-2-propoxyphenyl\}-7-propyl3,5 dihydropyrrolo [3,2-d]-pyrimidin-4-one (SK3530) in rats. Rapid Commun Mass Spectrom 2007; 21: 1139-49. 